\title{
The Future of Law and Economics
}


This page intentionally left blank 


\section{The Future of Law and Economics \\ Essays in Reform and Recollection \\ GUID O CALABRESI}

Yale UNIVERSITY PRESS

New Haven and London 
Copyright () 2016 by Yale University.

All rights reserved.

This book may not be reproduced, in whole or in part, including illustrations, in any form (beyond that copying permitted by Sections 107 and 108 of the U.S. Copyright Law and except by reviewers for the public press), without written permission from the publishers.

Yale University Press books may be purchased in quantity for educational, business, or promotional use. For information, please e-mail sales.press@yale.edu (U.S. office) or sales@yaleup.co.uk (U.K. office).

Set in Minion type by IDS Infotech, Ltd. Printed in the United States of America.

ISBN 978-0-300-19589-7 (cloth : alk. paper) Library of Congress Control Number: 2015940941

A catalogue record for this book is available from the British Library.

This paper meets the requirements of ANSI/NISO Z39.48-1992 (Permanence of Paper). 
To Kate, Sam, Adam, and Ginevra, who are the future 
This page intentionally left blank 